\title{
REHABILITATION AND TREATMENT BY MOVEMENT OF CONTRACTURES IN RHEUMATOID ARTHRITIS
}

BY

\author{
GUNNAR EDSTRÖM \\ From the Department and Clinic for Rheumatic Diseases, University Hospital, Lund, Sweden
}

(RECEIVED FOR PUBLICATION APRIL 15, 1952)

Rheumatoid arthritis is a mesenchymal process especially affecting the collagenous connective tissue. Most frequently the process is prolonged, progressive, and undulant, or, as Hench (1934) expresses it, "potentially reversible". By means of the 11-oxysteroids the activity of the process can now be more easily controlled than heretofore, in other words, " the fire can be extinguished" but " the ashes still have to be removed ". Deformities, contractures, and incorrect positions of the joints caused by the disease must be taken care of and corrected.

At present most of those who have become crippled by rheumatoid arthritis have not received sufficient assistance to "remove the ashes ". The right way to rehabilitation has been pointed out by Krusen (1951) in Rochester and by Rusk (1950) in New York. The same principles have been previously advanced by Fox and van Breemen (1934) in London and Amsterdam, by Ray (1937) in London, by Haglund (1923) in Stockholm, and by Plate (1922) in Hamburg. The importance of rehabilitation therapy has also been stressed in our department for the last 15 years (Edström, 1942; 1947; 1952a, b).

Although in rheumatoid arthritis the process is widely spread throughout the organism, the most advanced changes are generally observed in or around the joints.

As a general rule a diseased organ should have rest. From a biological point of view, however, this resting should not amount to complete nonfunction. In cardiac and renal disorders, for instance, rest can never be total. Non-function, undesirable from a biological standpoint, can be effected only by the postural and motor organs.

Disuse of a joint has a destructive effect on tissues and functional capacity. The experiments of Holmdahl and Ingelmark (1946, 1947, 1948), Ekholm (1951), and Sääf (1950) demonstrate that function strongly affects the structure of the osseous and cartilaginous tissues as well as the structure of the connective tissue. Normal movement is a⿳⺈.𠃌冖 factor which forms, regulates, and maintains thestructure. Prolonged incomplete function is des-i tructive in that the nutrition and structure of the bone, cartilage, and connective tissue are affected.

Therefore, a joint which has been attacked byد rheumatoid arthritis should not be fixed, for example, $\vec{c}$ in a circular cast for a long time, though a shorter $\infty$ fixation in a circular cast may be advisable, especially for reducing the activity in acute exudative arthritis, and is also suitable in flexion contractures as å traction cast. As a rule, however, such a fixation ${ }_{-}$ should not last more than one week, and after tifser the mobility of the joint must be exercised.

In destructive types of rheumatoid arthritis certain period of fixation is often necessary, especially when there is considerable pain onō movement. A wide range of joint motion is notö always our chief aim. The process must first bee arrested or healed, and this is impossible in $a_{\overrightarrow{0}}$ destructive process without absolute rest sufficiently 3 prolonged. Our rule is: Rather a painless joint with restricted motion or ankylosis in a good position than a more mobile joint with marked pain on movementov resulting in reduced function or non-function.

Another significant factor in rheumatoid arthritis is the mechanical hypersensibility sometimes encoun tered. Subcutaneous nodules may occur in areas? which have been exposed to blows, and a rheumatoid arthritic process can begin or recur in a joint which has been subjected to trauma. For example, $>$ arthritis can be produced by various traumas in experimental animals (Edström, 1951). On theses phenomena the physiology of the adrenal cortex has shed a new light.

Manipulations unnecessary for maintaining thew function of diseased joints should therefore be avoided, but some movement treatment is requirede in all cases of rheumatoid arthritis.

The ideal movement treatment in cases of rheu $\stackrel{\infty}{+}$ matoid arthritis is prophylactic, and is instituted at the very beginning of the disease to preven? 
contractures and incorrect positions. In a hospital a physiotherapist or nurse may regularly control the patient's joints, and the Arthritis and Rheumatism Foundation of New York has recently published a pamphlet entitled "Home Care in Rheumatoid Arthritis ".

Corrective therapy is called for when contractures or incorrect positions have already developed. Hospital care is necessary in severe cases, but contractures can occasionally be treated at home.

\section{Development of Contractures and Incorrect Positions}

Arthritic processes start as synovitis, spread gradually into the surrounding connective tissue, causing perioedema and exudation, and finally attack cartilage and bone tissue. In the later stages, exudative proliferative conditions occasionally predominate; exudative arthritis occurs often in combination with increased exudation in the joint. In other instances the exudation recedes, the synovial fluid and the perioedema are reduced, and degeneration and destruction ensue; the cartilage is destroyed, and the bone tissue becomes more and more ulcerated, especially in the smaller joints of the carpus and tarsus where all the small bones are sometimes fused together.

Contractures.-The acute stage of an arthritic process is often characterized by considerable swelling and pain, particularly on movement, and the patient holds the joint in the position which causes the least tension. This optimal position is usually a moderate flexion and if the joint is allowed to remain in such a relaxed position, contractile elements are affected and the range of movement is reduced, so that the patient cannot extend the joint fully nor flex it completely, and a flexion contracture has developed.

A flexion contracture of this type is very rarely entirely or partly caused by changes in the bone; this occurs only in late stages of the arthritic process where reactive bone changes have developed in connection with ulceration and destruction. Tension therapy is then fairly hopeless. As a rule, the contracture is brought about by changes in the soft tissue, sometimes in the musculature and the insertions of the tendons. The possibility of restoring by means of movement therapy a normal or functionally satisfactory range of joint motion will then depend upon the age of the patient and the degree of change in the soft parts. Prolonged, careful traction is usually more effective than violent manipulation.

Incorrect Positions.-These usually develop in a similar manner. Ulnar deviation develops in the metacarpophalangeal joints and the hallux valgusposition with lateral deviation develops in the metatarsophalangeal joints. In both these instances the incorrect positions are taken up because the morbid process causes an imperfect balance between the groups of muscles working on the joints in question.

In rheumatoid arthritis a more or less pronounced atrophy of the musculature occurs, but all muscles do not atrophy to the same degree. The atrophy may also occur on account of nutritional disturbances originating in the morbid process and not solely due to inactivity (Landoff, 1942). Large muscles are less sensitive to these disturbances than the small ones (Alwall, 1939), and the latter are therefore most markedly weakened. In addition to their flexion and traction function, these small muscles in the hands and feet possess a radially (medially) active component; the larger muscles of the forearm and the leg have an ulnarly (laterally) effective component. Thus, as a result of the irregular muscular atrophy, an increased pressure occurs on the ulnar (lateral) portion of the metacarpophalangeal (metatarsophalangeal) joints.

\section{Therapy}

Rest in Bed.-As in other chronic infections, prolonged rest in bed is often an important factor in the treatment of an early stage of rheumatoid arthritis. It must, however, be prescribed and supervised, and should be combined with exercise of the affected limbs.

As long as there is no contracture in any joint of the lower extremities the patient should get up every day for short periods to take care of his personal hygiene, leave the sick-room for a while, eat without assistance, and walk to his bath and treatments. Such mild daily exercise should also be combined with mild movement therapy. Febrile patients must remain in bed but the supervision of their joints should be even more careful.

An extended position often provides the most effective rest for the joint. The arthritic should avoid lying with crooked and flexed joints. Under no circumstances should knee-pads be employed. To avoid the development of talipes equinus through the weight of the cover, a foot-arch, foot-board, or foot-pads should be employed, and splints are often useful to keep the limbs extended.

Exercise Therapy while in Bed.-If the patient does not possess the strength to be up and about, one must start with exercises in bed. Arms and legs should be softened up by means of light active or assisting movements under the instruction of a physiotherapist or nurse. Appliances should be employed as soon as possible; they often have a stimulating effect on the patient, as he can then better observe his progress. 
An exercise apparatus for the musculature of the lower extremities is shown in Fig. 1. Electrical muscular exercise may also be given by means of a tonizator or some similar apparatus, using alternating current.

A similar apparatus (Fig. 2) can be used for exercising the muscles of the upper extremities. Those of the hand and lower arm are best trained with the aid of a comparatively firm rubber ball or hand strengthener.

Exercises out of Bed.-As soon as possible, when the patient is able to stand on his legs without contractures of the knee, for example, he should get out of bed and exercise in a gocart (Fig. 3a), and there should be special go-carts for children (Figs $3 b$ and $c$, opposite).

When the patient has control of his muscles, particularly the muscles of the legs, he may change to crutches, then gradually to handcrutches or canes, and finally he must walk alone without support. The transitions should not be forced. The training periods should not be too long, but should be given several times every day, with 1-hour rest intervals. After the musculature is strengthened, the exercise increases the range of motion of the affected joints.

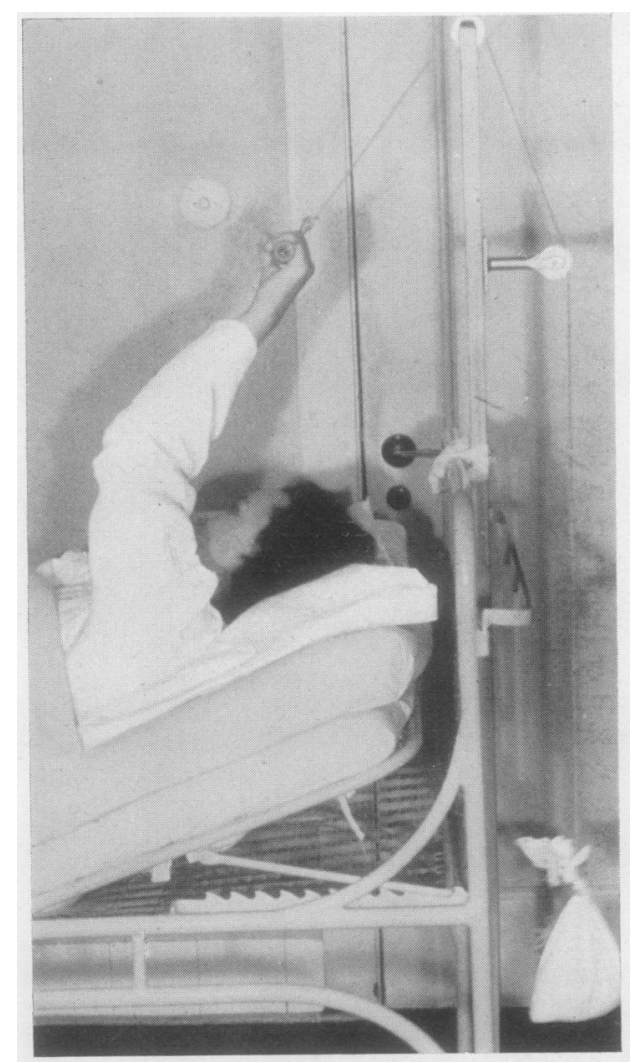

Fig. 2.-Exercise apparatus for musculature of upper extremities (for patients in bed).

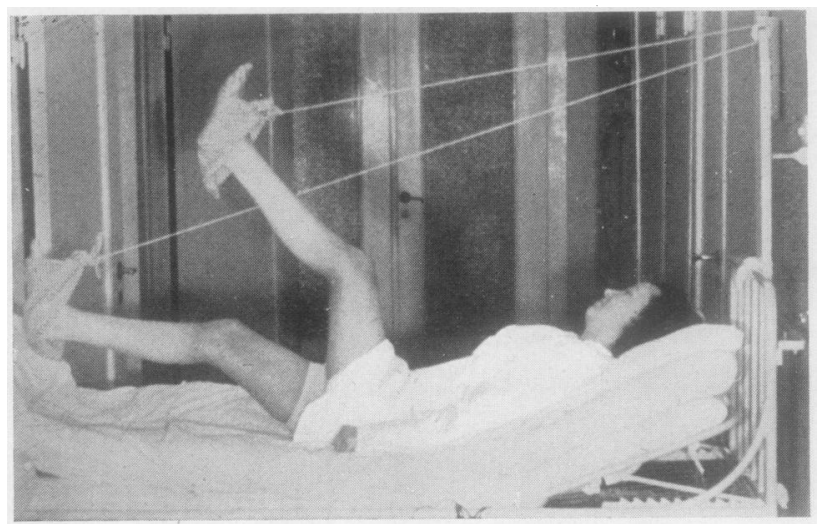

Fig. 1.-Exercise apparatus for musculature of lower extremities (for patients in bed).

Movement Treatment of Separate Joints.-The rule in movement treatment of arthritis is never to use more violence than is required. More manipulations of hard contractures were formerly performed under anaesthesia than is now usual. Haglund (1923) maintains that several small corrections without anaesthesia-only as much as the patient can stand-yield better results than a few powerful manipulations under anaesthesia, and my own experience of almost 25 years supports the view.

After more or less powerful manipulations havo been carried out, the joint should be allowed to rest for a few days. For this purpose a corrective cast is useful. These casts are particularly useful for excessive flexion contractures in the knee-joints. We employ casts by stages instead of one corrective $\overrightarrow{\overrightarrow{0}}$ manipulation of the joint under anaesthesia. We 3 start with 14 days' physiotherapy combined with traction, alternating with 8 days in a traction cast in as extended a position as is possible without anaesthesia. Even extension defects of 50 to $60^{\circ}$ ? can in this way be fully stretched in a few $\frac{5}{3}$ weeks without the development of a subluxation position.

It is important, with or without the use of corrective casts, that corrective exercise treatment be combined with energetic stretching or flexing by $\frac{D}{0}$ means of various auxiliary devices. In contrast to the Zander gymnastic apparatuses these may be $N$ quite simple: ropes, dumb-bells, blocks, sticks, etc. $N$ Heat treatment beforehand always facilitates the $N$ exercise therapy.

The principles and contrivances used in the Rheumatological Department in Lund for con- $\stackrel{\varrho}{=}$ tractures and incorrect positions of the different $\stackrel{D}{\mathscr{Q}}$ joints are illustrated below, but this report does not ${ }^{-}$ claim to be complete. 


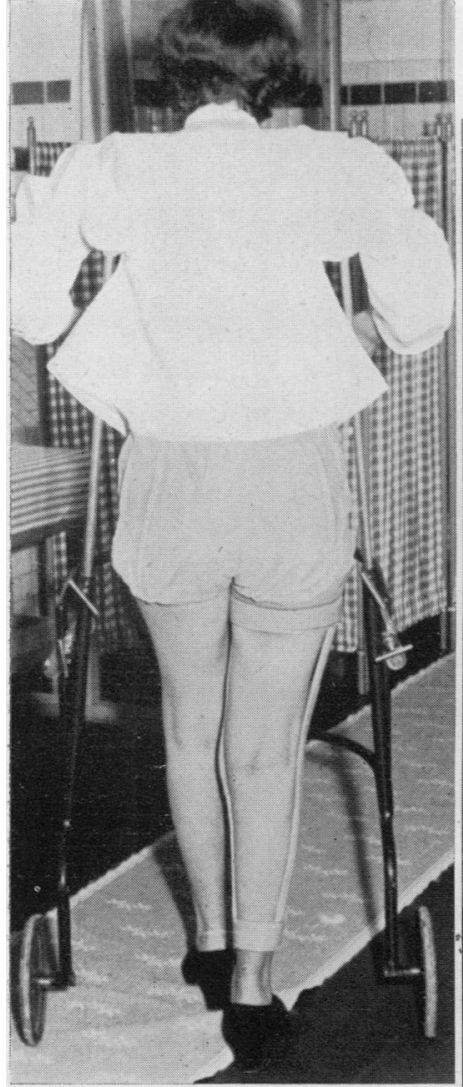

(a)

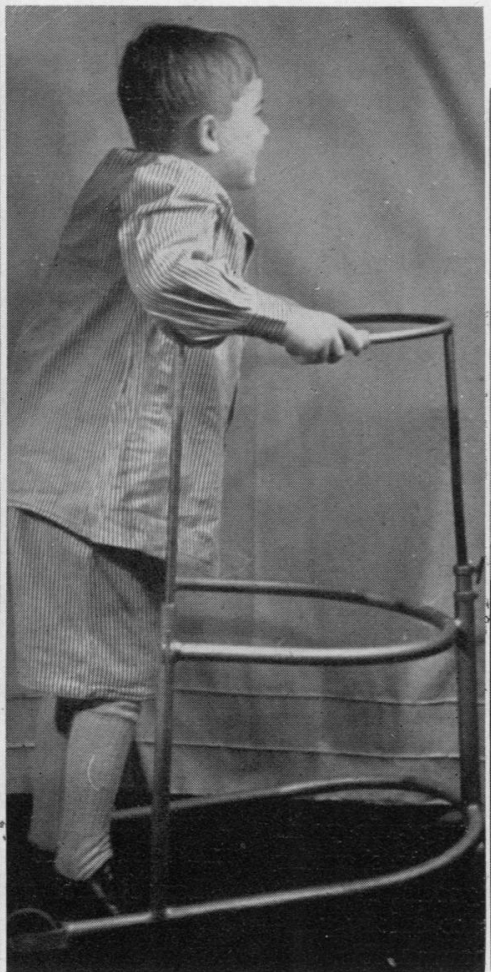

(b)

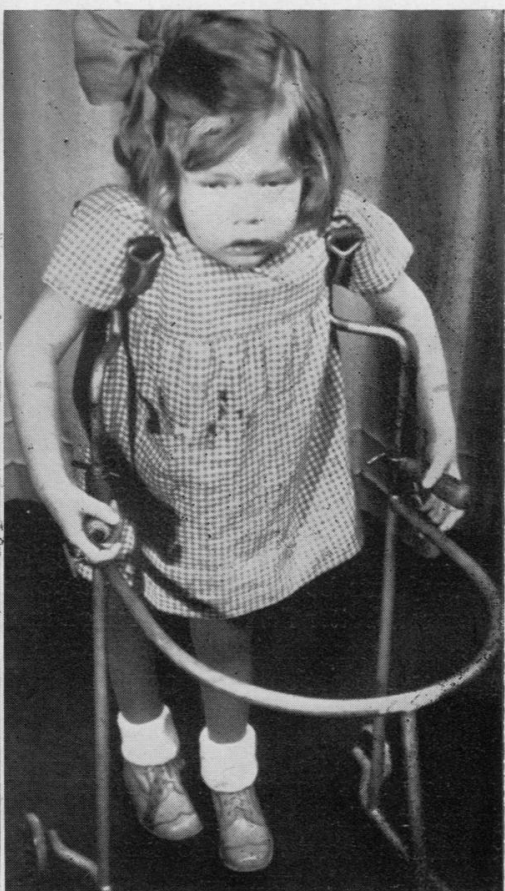

(c) (a) Hand and Finger Joints.-Rheumatoid arthritis has a predilection for the small joints of the hands and feet, where there is a pronounced tendency to destruction, incorrect positions, and contractures, but even an excessive deterioration of the bone or cartilage may sometimes be combined with a fair degree of function.

The essential function of the hand is the grip. It is not as important to be able to extend the fingers as to flex them and grasp with them. Inflexible fingers are best trained by the patient himself in a warm hand bath. Between times the fingers should be bound with an elastic bandage.

Finger contractures are often due less to arthritic processes than to peritendinitis in the flexor tendons of the fingers-flexor peritendinitis occurs in nearly 50 per cent. of our cases (Edström, 1945). It is important that the peritendinitic process be arrested by some suitable therapy, for instance, roentgenologic treatment. Surgical interference is rarely needed.

The best contrivance for strengthening the grasping capacity of the hand is a small rubber ball about $5 \mathrm{~cm}$. in diameter, with good elasticity, preferably constructed in one piece, which the patient can handle continuously, or a " hand strengthener" with comparatively soft springs.
The tendency to ulnar deviation in metacarpophalangeal joints should also be checked in time. We employ mostly night hand splints with finger divisions, preferably of light metal (Fig. 4).

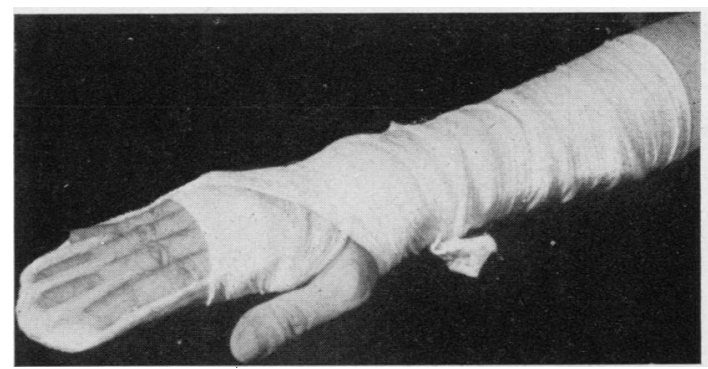

Fig. 4.-Night hand splint with finger divisions (light metal).

The process in the small joints of the carpus and radiocarpal joints is very frequently highly destructive. In most cases, therefore, it is advisable to strive after a comparatively painless wrist in a suitable position with a limited joint motion. Comparatively little movement 
treatment should be used, but instead fixation in an advantageous position by means of splints (Fig. 5) in a dorsal flexion position.

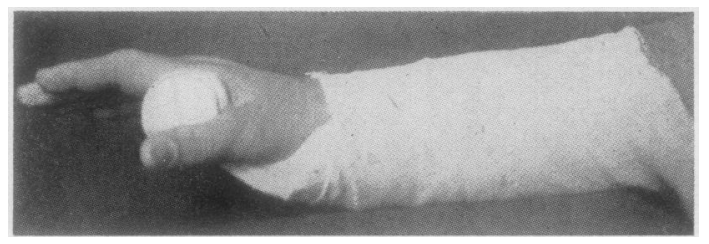

Fig. 5.-Night hand splint for the wrist (plaster of paris).

(b) Elbow Joints.-Contractures frequently occur here, and are difficult to correct without suitable devices. Figs $6(a)$ and $6(b)$ show how the same appliance is used for both traction and flexion. A fairly good flexion is required for patients' personal care in eating, washing, combing the hair, etc., and many occupations demand an even larger degree of extension. When the destruction present is considerable and no wide range of motion can be attained, it is important that the two elbow-joints be fixed in different positions, so that, for example, better flexion is obtained in the left elbow and greater extension in the right, careful attention being paid to the patient's occupation.

(c) Shoulder Joints.-From a kinesitherapeutic point of view it is important in contractures of the shoulder joint to distinguish between the diagnosis of periarthritic processes in the subdeltoid space chiefly peritendinitis and bursitis-and arthritis or omarthrosis.

In peri-arthritis, rather energetic physiotherapy should be used in order to correct the contracture-not only active training with various appliances but also passive and assisting exercises. Even manipulations under anaesthesia are sometimes called for. "The prognosis is good. If the tenderness on movement is pronounced, $x$-ray treatment sometimes gives relief, heat therapy being used in preparation. Massage, short-wave radiation; and diathermy often have an irritating effect.
When there is a peri-arthritic process in the subdeltoid space the arm should not be fixed in adduction by means of an arm sling (mitella). In acute or subacute conditions with great pain on movement a shorter $\frac{\text { ? }}{\text {. }}$ fixation may be done in abduction.

In arthritis in the humeroscapular and acromioclavicu- $\stackrel{\vec{D}}{\circ}$ lar joints, firm contractures, often accompanied by considerable pain on movement, frequently occur. The 흠 physiotherapy should then be lighter; the prognosis is $\frac{5}{7}$ poorer, but the important thing is to achieve satisfactory $\stackrel{\mathbb{Q}}{\Omega}$ abduction and rotation. Prophylactic treatment is 0 therefore very important to prevent the development of ${ }^{\text {is }}$ such adduction contractures. At an early stage the $\overrightarrow{0}$ patient should be given abduction splints, to be used several times daily, alternating with apparatus exercises. $\vec{\omega}$ Bed-ridden patients should be given pads in the armpits.

In omarthrosis the exercise treatment should be even $\overline{2}$ more cautious, and a short period of rest from the daily $\overrightarrow{\vec{H}}$ work often has a good effect.

(d) Toe and Ankle Joints.-Hallux valgus is often $\overrightarrow{\mathscr{C}}$ observed in rheumatoid arthritis. The more extreme $\mathrm{O}$ forms should be corrected by operation. The tendency to hammer toe and lateral deviation of the other toes are is also often favourably affected by operation.

All patients with rheumatoid arthritis in the foot joints should receive metal arch-supports with anterior pads (pelotes) at an early stage, since joints, fasciae, and liga- $\mathbb{Q}$ ments become weakened through the morbid process, and this results in excessive forms of pedes transverso-plate and pedes plano-valgi.

Lange's arch-support and orthopaedic shoes may alse be used to prevent deformation of the foot. Horribly deformed feet are only too common in rheumatoid arthritis but they may to some extent be prevented if remedial measures are adopted soon enough.

Contracted arthritic feet with more or less pronounced destruction of the small joints of the tarsus, which are also quite frequently encountered in rheumatoid arthritis, are best helped with orthopaedic shoes. An auxiliary apparatus for use in talipes equinus, and in talipes calcaneus with impaired motion of the talocrural joint, is shown in Figs $7(a)$ and $7(b)$.

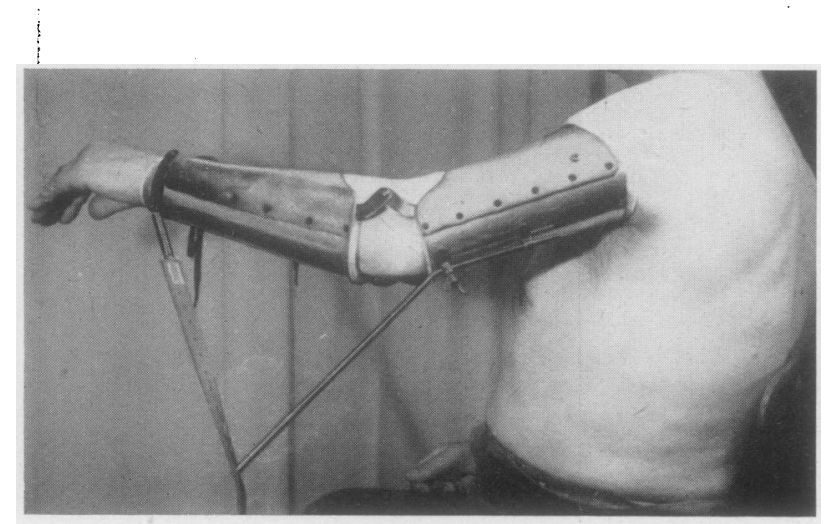

(a)

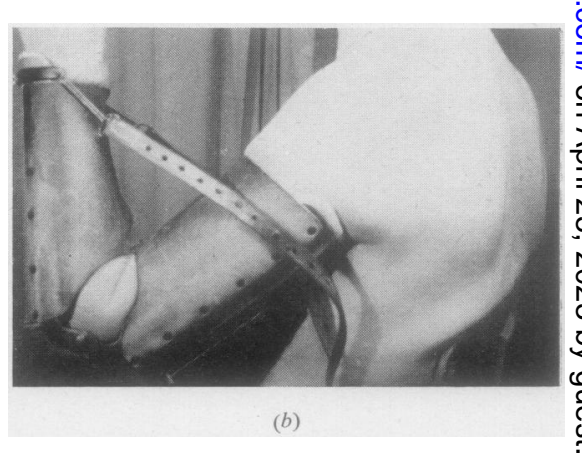

Fig. 6.-Apparatus for correction of contractures of $\square$ elbow joint, used as extension $(a)$ and as flexion $(b)$. 


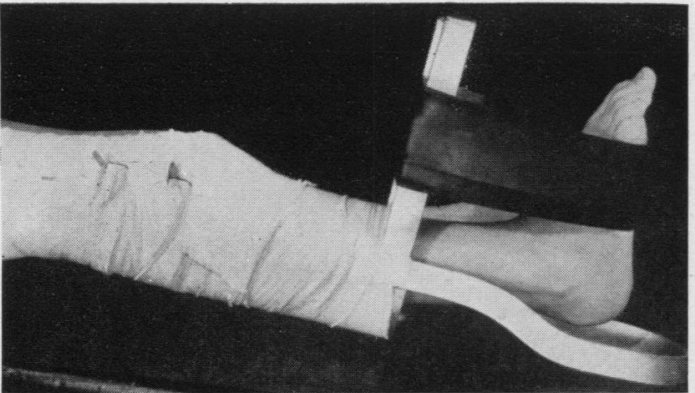

Fig. 7(a)._Apparatus for correction of dropped foot.

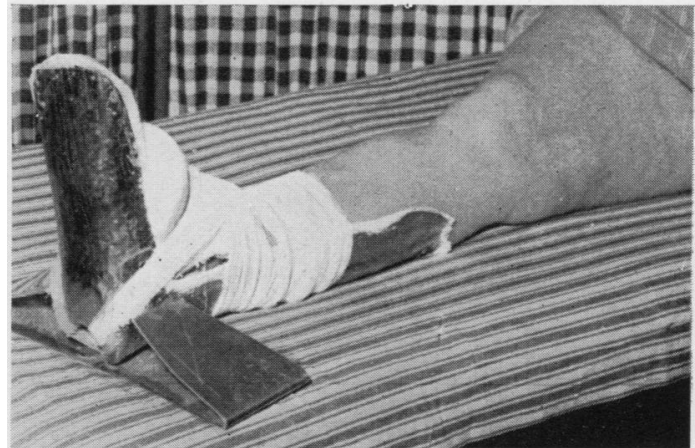

Fig. 7(b) -Apparatus for correction of dropped foot.

pronounced, traction should be introduced (Fig. 8a). The cuff around the ankle may also be fixed to a rollerskate which rolls along a board placed on the bed (see also Fig. 10). In this way the friction against the mattress and sheets is lessened and the traction becomes stronger.

When traction is used, the foot of the bed should be raised so that the body-weight of the patient counteracts the downward traction of the heavy sandbag. Children can be suspended, so to speak, in a more inclined position than adults by means of higher blocks under the feet of the bed (Fig. $8 b$ ).

Creutz's splint is another suitable appliance for the extension of flexion contractures in the knee joint. It can be especially recommended for after-care following a period of traction therapy, when there is a residual elasticity against full extension.
Fig. 8(a).-Traction of knee to correct flexion contracture.

A lower calcaneal spur caused by rheumatoid apophysitis should be treated with specially moulded metal supports.

(e) Knee Joints.-Flexion contractures of the knee joints are both common and incapacitating. As soon as any such tendency is observed, sand bags should be employed. They should not be placed directly on the patella since the surfaces of the bone and cartilage are often ulcerated and the weight would cause pain. A loosely stuffed bag, weighing 3 to $5 \mathrm{~kg}$., should be placed proximal to the patella, for 15 to 30 minutes, several times every day. A combination of active and passive movements is recommended.

When the flexion contracture is

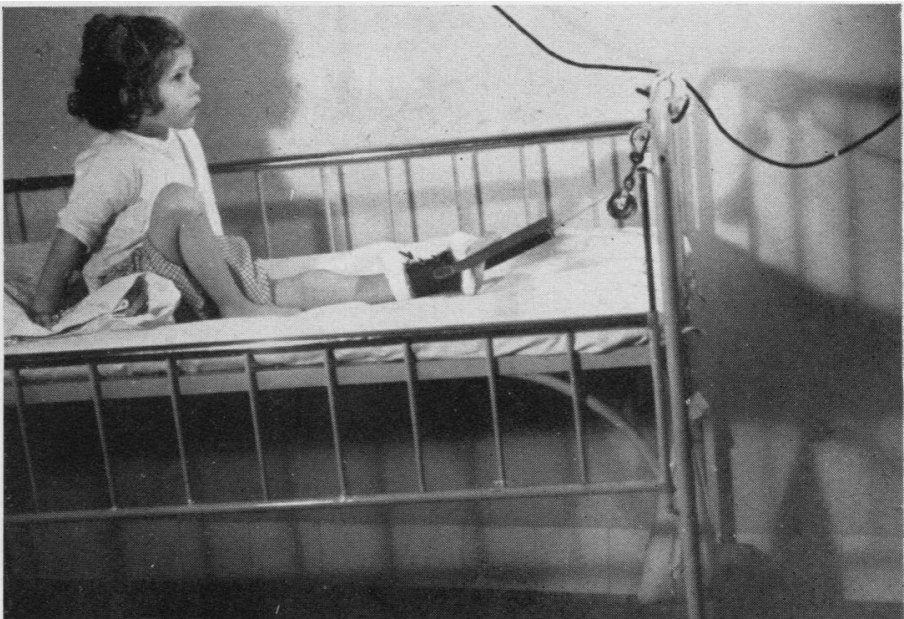

Fig. 8(b).-Traction of knee to correct flexion contracture. 


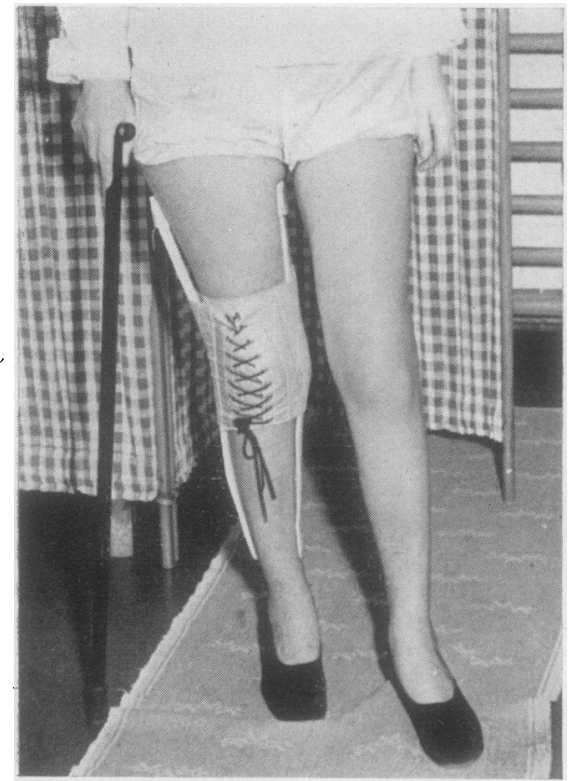

Fig. 9.-Creutz's splint for extension of knee to correct flexion contracture.

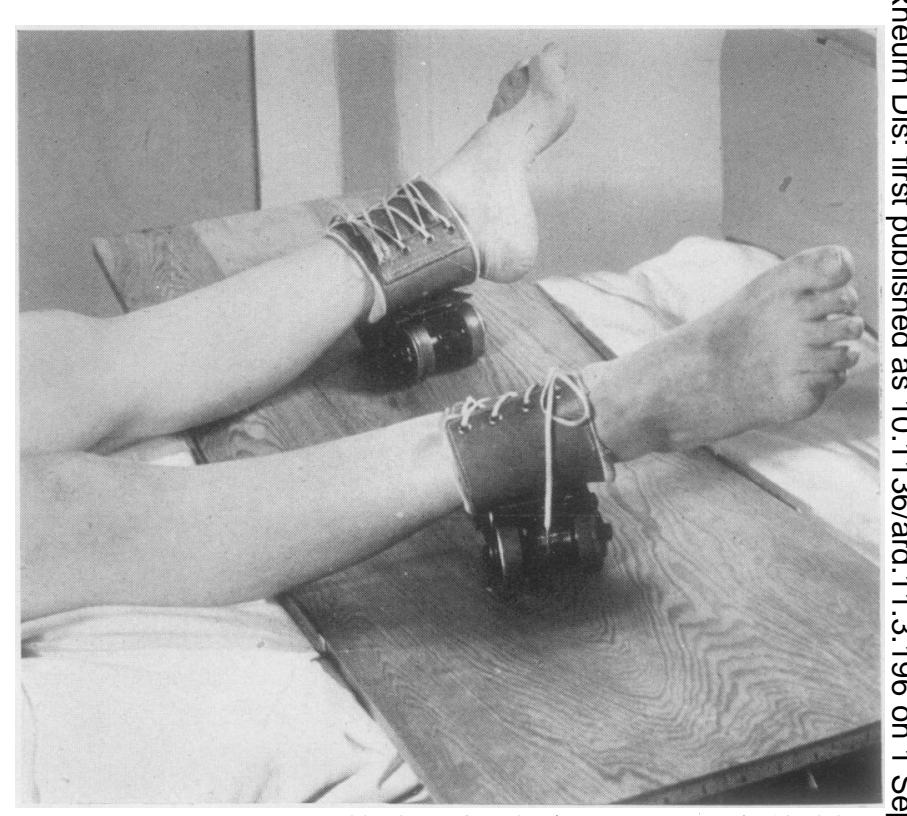

Fig. 10.-Apparatus for mobilization of abduction contractures in hip joints.
This appliance (Fig. 9) may also very easily be used by the patient in exercising the limb after leaving hospital.

(f) Hip joints.-These are less often affected by rheumatoid arthritis, but contractures, especially flexion and abduction contractures sometimes develop in them also. In dealing with flexion contractures which are often combined with similar deformities in the knee joints, the form traction described above (Fig. 8) is commonly employed. In abduction contractures we use the contrivance shown in Fig. 10, which can also be used with great advantage in abductions due to processes in the coxa.

(g) Spine.-In spondylarthritis ankylopoietica the tendency to stooping and round-shoulder should be arrested. The patient should from the very start be instructed to lie on a board without a pillow and to lie down two or three times daily on a flat surface to rest and extend the back. Two or three times daily he should perform a few minutes' exercises stretching the back. Corsets are not generally suitable.

Trachea central, no jugular vein pulsation, no cervical adenopathy. Right epitrochlear gland palpable and tender.

A patient in the pre-spondylitic phase can almost always be quite restored if he receives rational treatment at a special clinic. In the spondylitic phase we must strive to make the deformity as slight as possible.

(h) Jaw.-If the maxillae are affected by rheumatoid arthritis, contractures, often bilateral, are likely to occur, but they respond well to physiotherapy. The implement employed is a thick wooden spatula such as is used in forcing open the jaws under anaesthesia.

Heat Treatment.-Practical experience has long shown that medical movement therapy is almost always highly facilitated by a preceding treatment with heat. The patient thus experiences less paif $\overrightarrow{0}$ and his muscles are more relaxed.

Heat alleviates pain, probably because of its pero pheral vasodilatatory effect. The effect of heat therapy on the rheo-basis and chronaxia of the sensory nerves can be measured, and the absolute threshold has been found to be raised (Edström, 1932). Short-wave radiotherapy is not heat treatment in the same sense, for it causes no consensual vascular reaction and does not affect the rheo-base and chronaxia in the same way as the other forms of heat. Diathermy, on the other hand, can be utilized in the same way as hot air, electric pads, heat lamps, hot baths, hot packs, etc. Dry heat treatment is often to be preferred prior to movement therapy as it is less fatiguing.

\section{Summary}

The normal function of most mesenchymal organs and tissues is a factor in forming, regulating, and maintaining the structure. Long periods of norfunction have a deteriorating effect, especially on bone, cartilage, and connective tissue, which undergo structural and nutritional changes. Contractures and incorrect positions occur even more readily during periods of deficient function resulting from pathological conditions.

The control of the function of the extremities and limbs is, therefore, an important part of therapy 
in arthritis, especially rheumatoid arthritis. If patients receive inadequate supervision, contractures and incorrect positions develop, especially in knee, shoulder, hand, and foot joints. Such supervision should be exercised not only during hospitalization but also at home, the ideal treatment being prophylaxis. "Home Care in Rheumatoid Arthritis", published by the Arthritis and Rheumatism Foundation of New York, ${ }^{*}$ is recommended as a guide.

The correction of most cases of contracture and incipient incorrect position, as well as the subsequent exercise and training of extremities, muscles, and joints, is facilitated by simple gymnastic devices, such as ropes, balls, dumb-bells, blocks, canes, etc. The patient should learn to use these during hospitalization, as they are very important afterwards in home care, and stimulate rehabilitation both physical and mental. Complicated mechanical apparatus is less effective.

The movement treatment and simple auxiliary devices and gymnastic apparatus used in the University Hospital, Lund, are described.

\section{REFERENCES}

Alwall, N. (1939). Acta med. scand., 102, 258.

Edström, G. (1932). Hygiea, Stockh., 94, 396.

(1942). "Sjukgymnastik och massage vid Reumatism." Nord. Bokh., Stockholm

(1943). "Prinzipien der Bewegungstherapie in der Rheumatologie" (Der Rheumatismus, Bd. 27). Steinkopff, Dresden.

(1945). Nord. Med., 25, 379.

(1947). Brit. J. phys. Med., n.s. 10, 4

(1951). Rev. Rhum., 18, 507

1952a). Acta med. scand., 142, 11.

(1952b). Sv. Läkartidn. 49, 881.

Ekholm, R. (1951). Acta Anat., Basel, Suppl. 15

Ekholm, R. (1951). Acta Anat., Basel, Suppl. 15. Churchill, London

Haglund, P. (1923). "Die Prinzipien der Orthopädie." Fischer, Jena.

Hench, P. S. (1934). Ann. intern. Med., 7, 1278.

Holmdahi, D. E., and Ingelmark, B. E.'(1946). Acta med. scand. Suppl. 170, p. 568 .

- - (1948). Acta Anat., Basel, 6, 309

Ingelmark, B. E. (1947). Acta med. scand., 128, 203.

(1948). Acta Anat., Basel, 6, 193. Krusen, F., ed. (1951). " Year Book, of Physical Medicine and

-

Landoff, G. A. (1942). Acta chir. scand., Suppl. 71.

Plate, E. (1922). Münch. med.Wschr. 69, 1072 .

Ray, M. B. (1934). "Rheumatism in General Practice." Lewis, London.

Sääf, J. (1950). Acta orthop. scand., Suppl. 7.

Réhabilitation et mobilisation dans le traitement des contractures au cours de l'arthrite rhumatismale

\section{RÉSUMÉ}

La fonction normale de la plupart des organes et des tissus mésenchymateux est un facteur dans la formation, l'ajustement et le maintien de la structure. L'absence prolongée de la fonction a un effet détériorant, surtout sur l'os, le cartilage et le tissu conjonctif, qui subissent des altérations structurelles et nutritives. Des contractures et des positions défectueuses se produisent

* This pamphlet was reviewed in this Journal in the March issue. See Annals of the Rheumatic Diseases (1952), 11, 63. encore plus rapidement lorsque la fonction est insuffisante au cours des conditions pathologiques.

Il est donc important, en traitant l'arthrite, surtout rhumatismale, de contrôler la fonction des extrémités et des membres. Faute de surveillance suffisante des malades on voit apparaître des contractures et des positions défectueuses, frappant surtout les articulations du genou, de l'épaule, de la main et du pied. Cette surveillance est nécessaire non seulement à l'hôpital mais aussi au domicile, le but idéal du traitement étant la prévention. Comme guide, on recommande au malade "Home Care in Rheumatoid Arthritis (Soins à domicile de l'arthrite rhumatismale)", publié par The Arthritis and Rheumatism Foundation of New York.

La correction de la plupart des contractures et des positions défectueuses naissantes, ainsi que l'exercice et la rééducation subséquents des extrémités, des muscles et des articulations est facilitée par de simples dispositifs de gymnastique, tels que cordes, balles, haltères, poulies, cannes, etc. Il faut que le malade apprenne à s'en servir à l'hôpital en raison de leur grande importance plus tard, à domicile, pour stimuler la réhabilitation physique et mentale. Un appareillage mécanique compliqué est moins efficace.

L'auteur décrit les méthodes de traitement par la mobilisation ainsi que les simples dispositifs auxiliaires et les appareils de gymnastique employés à l'Hôpital de Lund.

Rehabilitación y movilización en el tratamiento de las contracturas en la artritis reumatoide

\section{Sumario}

La función normal de la mayoría de los órganos y de los tejidos mesenquimatosos es un factor en la formación, regulación y en el mantenimiento de la estructura. Una ausencia prolongada de la función tiene un efecto perjudicial, especialmente sobre el hueso, el cartílago y el tejido conjuntivo, que sufren alteraciones estructurales y nutricios. Contracturas y posiciones defectuosas ocurren más rapidamente aun cuando la función es insuficiente en el curso de las condiciones patológicas.

El control de la función de las extremidades y de los miembros tiene, pues, gran importancia en el tratamiento de la artritis, especialmente de la artritis reumatoide. A falta de vigilancia adecuada de los enfermos, contracturas $y$ posiciones defectuosas aparecen, particularmente en las articulaciones de la rodilla, del hombro, de la mano y del pie. Tal vigilancia es necesaria no sólo en el hospital sino también en casa, el objeto ideal del tratamiento siendo la prevención. Para guíarle, se puede recomendar al enfermo "Home Care in Rheumatoid Arthritis (Cuidado domiciliario en la artritis reumatoide)", publicado por The Arthritis and Rheumatism Foundation of New York.

Para facilitar la corrección de la mayoría de las contracturas y de las posiciones defectuosas incipientes, así como para favorecer los ejercicios y la reeducación subsiguientes, se hace uso de simples utensilios de gimnasia, como cuerdas, pelotas, palanquetas, poleas, bastones, etc. El enfermo debe aprender a manejar estos dispositivos mientras esté en el hospital ya que luego, en su casa, adquerirán gran importancia por estimular la rehabilitación física y mental. Aparatos mecánicos complicados son menos eficaces.

El autor describe los métodos así como los simples dispositivos auxiliares y los aparatos de gimnasia empleados para la movilización en el Hospital de Lund. 